\title{
Gender Role Attitudes and Parents' Intention to Continue Childbearing in Turkey
}

\author{
Serap Kavas
}

\begin{abstract}
It is increasingly acknowledged that gender (in-) equality is one of the most significant factors underlying change in fertility behavior. Researchers have extensively studied the link between gender (in-) equality and fertility decisionmaking in various settings. However, most of these studies have focused on industrialized countries in North America, Europe, and East Asia, while very few examine this relationship in a non-western, developing country context. Employing individual-level survey data, this paper examines the relationship between parents' gender role attitudes and their fertility intentions for an additional child in urban Turkey, surveyed in 2014. The findings of this study show that parents' attitudes toward gender roles were not an important predictor of fertility decision-making in Turkey. This study suggests that the lack of significant findings supporting the expected association may be related to the measurement of gender role attitudes, suggesting a need to construct a measure that addresses culture-specific aspects of gender roles. This study contributes to the literature by providing a new data point, Turkey, and bringing a comparative perspective to the existing research.
\end{abstract}

Keywords: Gender (in-) equality · Fertility decisions · Survey data · Turkey

\section{Introduction}

Fertility rates have fallen dramatically over recent decades in many countries across the world. For example, the phenomenon of "lowest-low fertility levels" has surfaced in Central and Eastern European countries (Kohler et al. 2002), and East Asia has also become a region marked by low fertility. Moreover, examples of nonwestern low-fertility patterns can be extended to the Middle East. Countries in this region of the world are at different stages of a transition from high to low fertility, with total fertility rates hovering around replacement level, such as in Lebanon and Tunisia (Assaad/Roudi-Fahimi 2007). 
Many theories have been offered to explain low fertility, including increasing individual autonomy and increasing age at first marriage (e.g., Caldwell/Schindlmayr 2003); postponement of childbearing due to economic uncertainty, and the opportunity costs of childbearing (e.g., Kohler et al. 2002). Recent research has drawn increasing attention to the relationship between gender equality and fertility behavior. McDonald's (2000a/b) gender equity theory in particular postulates that the decline in fertility is largely related to the inconsistency between increased gender equality in institutions of education and labor markets on the one hand and relatively low levels of gender equity in family and family-related settings on the other. Building on the gender equity framework, gender revolution theory has suggested that gender egalitarianism in both the public and private spheres will increase fertility in low-fertility countries. In particular, as men increasingly participate in domestic chores and childcare, and thus share the burden of work and family life, women will be willing to have more children (Goldscheider et al. 2015).

An extensive literature has studied the association between gender equality and fertility behavior in various settings, reporting mixed findings (e.g., Arpino et al. 2015; Brinton/Lee 2016; Miettinen et al. 2011; Mills et al. 2008; Oláh 2003; Puur et al. 2008; Torr/Short 2004). The previous literature exploring this association has focused largely on the European context, though there is also an emerging literature on non-western settings, most of which focuses on low-fertility countries in East Asia (e.g., Brinton et al. 2018; Freeman et al. 2018; Kan/Hertog 2017; Yang 2017). There is a gap in the literature with regard to examining the gender equality-fertility relationship in more diverse settings with "nation-specific contextual explanations" (Mills et al. 2008). This study builds on the previous literature and expands the research on the gender equality-fertility relationship by examining Turkey; a new socio-cultural setting and understudied context.

This study provides an empirical analysis of the association between gender (in-) equality and low fertility in Turkey, a Muslim country with persistent yet highly variable gender equality problems. While there have been many political reforms since the founding of the republic to change women's societal circumstances, when it comes to public attitudes on gender roles, Turkey represents a quintessential example of "the stalled revolution." The country has had idiosyncratic gender relationships and declining fertility for the past several decades. Fertility rates are currently below replacement level, with the western parts of the country already having experienced below-replacement fertility for the past decade. The persistent fertility decline has sparked considerable concern among politicians and the public, leading the current government to expend considerable efforts on encouraging higher fertility (Kavas 2019). This study focuses on fertility intention, which is an important motivational antecedent of the fertility-related behaviors of individuals (Miller 2011: 76). This study contributes to this literature by testing the gender equality-fertility relationship in an understudied socio-cultural setting, offering a comparative perspective. 


\section{Background}

There has been growing interest in the gender ideology-fertility relationship since Becker's (1985) "new home economics" paradigm, which pointed to a strong interaction between women's increasing labor force participation coupled with changes in the sexual division of labor and declining fertility. More recently, McDonald $(2000 \mathrm{a} / \mathrm{b})$ has provided an explanation of the link between unequal gender norms and fertility outcomes. In oft-cited works, McDonald suggests that the decline in fertility to replacement level is linked to an improvement of equity in the family sphere, where women have achieved the right to control their parenthood decisions. However, further declines in fertility below replacement levels is related to the imbalance between high gender equity in institutional settings and the lack of a corresponding increase of equality in family settings, with the result that women respond to the disproportionate burden of the "double shift" by limiting their fertility. McDonald's theory (2006) sheds some light on the issue of desired/ideal fertility versus completed fertility, arguing that due to the unintended consequences of changing social and economic institutions, individuals may not be able to achieve their ideal fertility. Forgoing their ideal family size, women in particular state that "in a different institutional setting, they believe they would have had more children" (McDonald 2006: 485).

\subsection{Previous works}

Gender equity theory has increasingly attracted demographers' attention, with numerous studies testing this theory using either a macro- or micro-level empirical approach. In general, studies have used survey data to investigate the association between gender equality and fertility outcomes. These approaches either focus on the household division of labor or on people's gender role attitudes, and have reported mixed findings (e.g., Arpino et al. 2015; Brinton/Lee 2016; Cooke 2009; Miettinen et al. 2011; Mills et al. 2008; Mills 2010; Oláh 2003; Puur et al. 2008; Torr/Short 2004; Westoff/Higgins 2009). Of special interest to demographers in this tradition has been the variation in the impact of gender equality on fertility by gender. For example, using the Population Policy Acceptance Study for eight European countries, Puur et al. (2008) explored the impact of men's role orientations on their fertility intentions, finding that men with an egalitarian attitude both had a higher desire to have children and a higher number of children than men with traditional views did.

For women, egalitarian attitudes may yield higher fertility if it is combined with men's increasing participation in household tasks. Cooke (2009) examined two countries, Italy and Spain, analysing the likelihood of having a second child within married couple households. The author suggests that when women receive help from their partner with household chores and childcare tasks, the likelihood of having a second child increases, although this effect was only significant in Italy. Numerous other studies have focused on the impact of men's changing roles in the family, both on their fertility aspirations as well as their partners'. Overall, these scholars 
draw attention to the notion of "fertility recovery," which indicates that when there is equality in the family, with husbands sharing both domestic chores and childcare, partner relationships become more fulfilling and consequently partners have an increased desire to continue childbearing (Brinton et al. 2018; Freeman et al. 2018; Goldscheider et al. 2015; Kan/Hertog 2017; Oláh 2003).

While ample evidence suggests a positive correlation between egalitarian gender role attitudes and fertility rates, other studies have found no significant relationship between the two. Chief among these works is Philipov's study (2008), which examined ten European countries and employed three dimensions of genderegalitarian attitudes. He found no clear association between the three gender dimensions and fertility intentions for the second or higher-order parity.

Moreover, some of these studies present contrasting findings, despite largely using the same data sets and measurement. For example, Puur et al. (2008)'s finding that egalitarian attitudes among men in eight European countries are positively correlated with higher fertility desire and realization was countered by Westoff and Higgins's (2009) recent work, in which the authors designed a similar study yet found a diametrically opposed relationship between the egalitarian attitudes of men and their actual fertility outcomes.

\subsection{Measuring Gender Equality and Fertility}

Empirical studies have provided mixed or conflicting evidence concerning gender equality and fertility relationship (e.g., Arpino et al. 2015; Goldscheider et al. 2010; Miettinen et al. 2011). The measurement of gender equality seems to be the most widely-stated challenge in the literature (Arpino et al. 2015; Brinton/Lee 2016; Davis/Greenstein 2009; Goldscheider et al. 2010; Knight/Brinton 2017; Miettinen et al. 2011; Puur et al. 2008; Torr/Short 2004; Westoff/Higgins 2009). Some scholars suggest that widely-used survey indicators may not be measuring gender equality thoroughly (e.g., Brinton/Lee 2016; Knight/Brinton 2017; Mills 2010), while others argue that the survey indicators may in effect function as a "surrogate" of the concept (Arpino et al. 2015).

Others draw attention to the complexity and multidimensionality of gender equality, noting that commonplace approaches of classifying gender role attitudes as a linear continuum from traditionalism to egalitarianism may not adequately depict the historical trajectory of change or the cross-cultural distinctions in gender norms (Knight/Brinton 2017; Brinton/Lee 2016). As Hudde (2018) argues, there is no reason to construct gender ideologies as binary concepts of either traditional or egalitarian while societies adopt various gender relations ranging from gendersymmetric models to alternative forms such as "the one-and-a-half earner model" or "the returning to the more traditional norms of gender roles". In line with this, in a study, Grunow et al. (2018) constructed five gender ideology profiles and found multidimensional gender ideologies to be more prevalent among the respondents than unidimensional constructs. The authors also found that egalitarian ideologies, which reflect joint spheres of earning and caring, intensive parenting and egalitarian 
essentialism were more prevalent in all the European countries examined in this study.

Measuring gender equality by attending to cross-cultural variations is crucial in that it helps us better understand distinctions in gender-role attitudes. For one, not all countries have the same gender systems; no matter how close geographically or culturally they are to each other, their norms and practices may still be highly variable (Goldscheider et al. 2010; Mills et al. 2008). Much evidence exists regarding the varying nature of gender equality across societies, including its differential effects on fertility behavior (Arpino et al. 2015; Goldscheider et al. 2015; Knight/Brinton 2017; Mills 2010; Mills et al. 2008). For example, using data from two countries with very low fertility (Japan and Spain) and two countries with slightly higher fertility (the United States and Sweden), Brinton et al. (2018) investigated how gender inequality may generate a gap between women's fertility ideals (hypothetical aspirations) and intentions (realistic aspirations) in all four countries. They found that while American and Swedish female interviewees were more likely than those in Japan and Spain to mention unequal gender roles as a reason for their fertility ideals and intentions gap, gender inequality was more significantly associated with low fertility intentions among highly educated interviewees in Japan and Spain.

Studies operationalize fertility outcomes differently. While most research focuses on continued childbearing for different parities (e.g., Cooke 2009; Miettinen et al. 2011; Torr/Short 2004), a large body of literature also examines fertility intentions (e.g., Brinton et al. 2018; Kan/Hertog 2017; Mills et al. 2008; Mills 2010; Okun/RazYurovich 2019; Tazi-Preve et al. 2004; Yang 2017). Brinton et al. (2018) draw a fine line between fertility ideals and intentions. The authors describe fertility ideals as more hypothetical aspirations without consideration of one's specific family situation, whereas intentions are more realistic plans that include the constraints that individuals perceive in reaching their ideals. Thus, "fertility intentions lie inbetween family size ideals and completed fertility" (Brinton et al. 2018: 281).

\subsection{Gender roles and family life in Turkey}

Family relationships and demographic patterns are key areas that clearly display the continuity and change that characterize social life in Turkey. Since the founding of the republic in 1923, Turkey has undergone an intensive modernization experience, which persists to date with Turkey's ongoing bid to join European Union. The stateled modernization project led to many changes in demographic and family behaviors, including increases in the age at first marriage, divorce rates, declines in fertility, more egalitarian gender roles, and more independence among young people. Regarding women's status, in particular, republican reformers staunchly supported improving women's circumstances through increasing education, employment, and political participation. After the founder of the Turkish Republic, Mustafa Kemal Atatürk, successive governments maintained his legacy by implementing this modernization/ secularization agenda, which included policy actions aiming to reduce gender inequalities (Aksoy/Billari 2018). Legal reforms in particular continued in line with Turkey's efforts to align with European Union standards. Substantial amendments 
were made to the civil code in 2003 , bringing about significant changes with respect to gender equality. For example, the amended civil code increased the legal age of marriage to 18 for both sexes, which had previously been 17 for men and 15 for women. It also introduced the legal basis for the sharing of marital assets in case of divorce, and adopted the legal measures to ensure equal status of wife and husband in the family (IIkkaracan 2007).

Importantly, reforms related to gender roles and family life faced severe opposition from conservative circles and despite all legal changes and reforms, traditional and authoritarian family practices remain widespread in the country (Cindoğlu et al. 2008), making hybridity an important feature of family life in Turkey (Kavas/Thornton 2013). Moreover, the current conservative government's efforts to "protect and strengthen families" contributed to this hybridity (YIImaz 2015; Kaya 2015; Yazıcı 2012; also see Aksoy/Billari 2018). For almost two decades, conservative discourse and political debates about the need to increase fertility, eliminate abortion and family planning, and traditional norms about women's roles in the family featured prominently current government's policy agenda.

In Turkey, marriage and having children are important pillars of family formation, and couples without a child do not fit into the mainstream definition of "family" broadly accepted by the population. Turkish family norms equally denounce being unmarried and being married and childless, and thus voluntary childlessness is almost non-existent in Turkey (HUIPS 2014).

The notion of a strong family bond, interdependence among family members, and a strong generational hierarchy are deeply entrenched, positively valued, and remain highly prevalent in Turkish society (Sunar/Fisek 2005). Turkish parents are generally protective of and expect obedience and dependence from their children (Kağıtçıbaşı 1982), and stay continuously involved in adult children's decision-making concerning important family issues (Nauck/Klaus 2008). Parent-child relationships, particularly in urban middle-class Turkish families, are characterized by emotional closeness and relatedness, especially between mothers and daughters (Ataca) Sunar 1999).

In Turkey, young women are socialized into normative gender roles according to which women are expected to be embedded into a family setting through marriage and childbearing and play the roles of mothers and wives, while husbands are the head of the family. In fact, before the 2003 civil code reforms, the traditional gender roles classifying men as breadwinners and heads of families and women as homemakers were even legally supported (I/kkaracan 2012). Marriage is almost universal, and although the minimum legal age at which marriage can take place is 18 , young people can get married at the age of 17 with parental consent, and at the age 16 with the approval of a judge.

With respect to gender roles, social class and urban-rural variations matter. Therefore, given the institutional changes over the decades and the great variability and heterogeneity of women's status, it would be a mistake to consider women in Turkey as passive victims of patriarchal norms and social rules (Kağıtçıbaşı 1986; Cindoğlu et al. 2008). For example, educated and high-income women tend to have more liberal attitudes toward gender roles, tend to be more resistant to patriarchal 
norms, and more willing to embrace changing social norms. Moreover, studies reveal that there are changes in attitudes to gender roles, particularly in the urban, middle-class, and professional population of Turkey (e.g. Aycan 2004; Aycan/Eskin 2005). A study reports that a higher number of men than before share domestic responsibilities in Turkey (Aycan 2004).

\subsection{Statement of the problem and research questions}

This study aims to shed light on the gender ideology-fertility relationship in Turkey. It uses the gender-equity framework, which suggests that the imbalance between the higher gender equity in the public sphere and lower improvements of equality in family life leads to fertility decline, with women responding to the disproportionate burden of domestic works by limiting their fertility (McDonald 2006).

The persistent fertility decline since the 1950s is the central theme in Turkish demographic discourse (Yavuz 2006). The total fertility rate (TFR) fell from a high of 7.1 children per woman in 1930 to 4.3 in 1978, 3.1 during the late 1980s, 2.1 in 2009, and most recently below replacement level, at 1.88 in 2019 (Turkish Statistical Institute (TurkStat) 2020). According to the Demographic and Health Survey (2008), western regions of the country have already been experiencing below-replacement fertility for many years, with a TFR of 1.7 in 2008 . The reasons for the decline in TFR over the years are generally explained with the socio-economic development the country has experienced for the past several decades and the changing status of women, especially regarding education (Akadlı-Ergöçmen 1997; D'Addato et al. 2007; Yavuz 2006; Koç et al. 2014). For example, Akadlı-Ergöçmen (1997) highlighted a strong relationship between women's status and fertility decline. Using demographic and health survey data, she found that women with five or more years of education, a job with social security, and a say in their marriage arrangement, as well as increased age at first marriage, tend to have fewer children. Moreover, a recent study found a connection between gender inequality and fertility outcomes in Turkey (Kavas 2019). Using in-depth interviews with mothers, Kavas (2019) found that women's shouldering larger shares of housework and childcare seemed to be an important reason for decreasing fertility in Turkey. In yet another study, the division of housework was found to be a significant indicator of women's fertility intentions in Turkey; using demographic and health survey data Berktaş (2016) found that when having a higher share of housework responsibilities, women in the 25-34 age group had a lower desire for more children.

Therefore, given its persistent fertility decline over the years and women's status that is replete with ambivalence and paradoxes, Turkey seems to be a relevant place to study the relationship between gender equity and fertility. Moreover, since much of the literature on gender equality and fertility focuses on industrialized countries in the West, where more egalitarian gender roles characterize social life, it would be interesting to explore this relationship in a non-western developing country context where there is great variability concerning gender roles, with considerable continuity and change. 
Toward this end, the first research question of this study is whether there is an association between parents' gender role attitudes and their fertility intentions for an additional child in Turkey. In particular, the study aims to explore the role that gender egalitarianism plays in fertility decline.

As discussed, this study argues that despite the efforts made since the founding of the republic to improve women's status in society, gender inequality persists, most palpably in the family sphere. With respect to access to education, girls' primary schooling is universal, and secondary and tertiary net enrolment rates were 66 and 32 percent respectively in 2011 (World Bank, gender equality report, 2012). However, when it comes to the provision of social policy measures to facilitate workfamily balance, Turkey cannot claim to have a particularly supportive labor market environment (I/kkaracan 2012). Housework and childcare are largely women's responsibilities, with the most recent nationwide family structure survey reporting that 86 percent of mothers are the main childcare providers (TurkStat 2016). In this context, parents with egalitarian attitudes may expect a more supportive environment with respect to equality in role sharing and public policy and may have a lower desire to have children than those with traditional views, who tend to take unequal gender roles for granted.

The second research question asks whether or not the influence of gender role attitudes on fertility persists once background factors are controlled for. According to Kandiyoti (1995), male dominance in Turkey was redefined and renegotiated over the past decades, with changes depending on geography and socioeconomic status. As a result, Turkey has become a country where multiple family gender cultures have coexisted. Parents' levels of education, employment status, ethnicity, etc. may play a role in their gender role attitudes. Therefore, it is important to know how these structural factors interact with gender norms and influence fertility decisionmaking.

The third research question concerns the extent to which these structural factors, which are known to affect fertility decision-making generally, influence fertility intentions independently of gender role attitudes in Turkey.

\section{$3 \quad$ Method}

\subsection{Data}

The data used in this study are drawn from a larger survey project titled "Fertility, Family Life and Developmental Idealism in Urban Turkey", designed to study views about fertility and family life in Turkey, which includes a module on gender ideology. Data were collected in 2014 through face-to-face interviews with randomly selected men and women of reproductive age (18-49). A multi-stage stratified sampling 
procedure was employed to attain samples in 17 cities. ${ }^{1}$ Interviews were held with individuals residing in households located in randomly selected neighborhoods, with the selected blocks consisting of 20 households. The main rationale for limiting the sample to cities was the very high costs of national surveys that include rural areas. This means that the results of this study can be extrapolated only to urban Turkey and not to the country as a whole. Furthermore, under the assumption that people in cities likely have more egalitarian attitudes than those in rural areas, the exclusion of the latter would reflect higher endorsement of egalitarianism in the urban sample compared to a national sample. However, it is important to note that with the current geographical distribution of the population, Turkey's urban areas are becoming increasingly heterogeneous by including substantial rural communities. In Turkey, a massive rural-to-urban migration has characterized the population structure of the country since the 1950s. It continued for several decades, increasing the percentage of the population that is urban (Erder 2002). In 2012, the proportion of the population living in the cities was 77 percent, and currently it is 93 percent (TurkStat 2020). So, given this heterogeneous geographical distribution of the population, it may be difficult to predict how different the urban results would be from results with a national sample.

A sample of 2034 individuals from all regions of the country was successfully interviewed, yielding a response rate of 51 percent. However, due to the research focus of this study, the sample is limited to married parents between the ages of 18 and 49, reducing the study sample to 1120 respondents. After this restriction, an analytical sample of 444 men and 676 women was included in the regression analyses, with slightly fewer observations in the multivariate analyses due to missing data (Table 4 and 5). Based on the specific research questions, the study prioritized the inclusion of men and women with at least one child. The reason for not including childless married couples is that the transition to parenthood happens almost as a matter of course in Turkey. As noted above, lifetime childlessness is very rare in Turkey, with family norms denouncing childlessness. Parents are influential in reproductive decision-making, typically wanting grandchildren and exerting pressure on adult children to produce offspring soon after marriage (Kavas/De Jong 2020; Nauck/Klaus 2008). Thus, as in many other social settings, in Turkey "the normative pressure to become a parent" (Rindfuss et al. 1988) obliges married individuals to have a first child early, which obscures other factors that should shape fertility decision-making. Thus, in a social environment in which couples are expected to have a child quickly, it is difficult to disentangle the effects of people's attitudes on gender roles on their fertility decision-making for the first birth. However, the transition to second or higher-order births is the stage when the cost and benefit of having additional children are considered more carefully (Olah 2003), and therefore this life-course transition is more conducive to examining the

1 The sampled cities from different regions of the country are as follows:

Adana, Ankara, Antalya, Bursa, Diyarbakir, Erzurum, Istanbul, Izmir, Kayseri, Kocaeli, Konya, Malatya, Manisa, Samsun, Şanliurfa, Tekirdağ,Trabzon 
influence of gender role attitudes on the decision to have a child. Moreover, because in Turkey childbearing almost universally takes place within marriage (HUIPS 2014), the sample consists entirely of married parents.

\subsection{Measures}

The dependent variable, fertility intention, was measured by asking whether or not the respondent planned to have (a/another) child sometime in the future, with the answers categorized as $\mathrm{No}=0$ and Yes $=1$. Pregnant couples were excluded. Gender role attitudes were measured with twelve statements presented below. These attitudinal questions on gender ideology evince respondents' views on gendered roles in the spheres of work and family, and have been used in several surveys including the World Values Survey, European Values Study (e.g., 1999), and other research (e.g., Brinton/Lee 2016; Westoff/Higgins 2009). An exploratory factor analysis was performed on these twelve categorical variables (Table 1). The analysis of factor loadings and the conceptual overlap between items led to the conclusion that there are two main gender ideology clusters, with the items in each group loading together significantly. The first gender role attitudes scale (GRA-1) was measured with six statements, with Cronbach's alpha for these items being .61.

The first three items in the first set of questions seem to address individualism in general rather than gender equality in particular, they address a women's independence as a single mother and whether an individual should be able to choose to be unmarried and childless. Therefore, they are relevant to women and men living in society without fitting a mainstream definition of family life, so I believe they still assess some aspects of gender equality (see Westoff/Higgins 2009). The remaining items in this scale capture respondents' gender role attitudes toward husbands' and wives' work roles, including the importance of a job for a woman's independence, women's ability to shoulder both family and work commitments, and whether men and women should equally contribute to family income.

The second set of questions in the second scale (GRA-2) (all reverse coded) focuses more on men's and women's roles in family life and contains the following items, with a Cronbach's alpha score of .51. (Table 1). These questions address gender roles in family life and stress, for example, women's "innate" role as caregivers and housewives, the necessity of having a child to be fulfilled, the primacy of parenthood over individual choices, and perceptions of women's desires to stay at home rather than work. Also, given the framing of these questions, it seems that these items tend to measure traditionalism more directly than egalitarianism, in that agreement with any of these statements will reflect a traditional attitude (Knight/Brinton 2017).

In sum, while questions in the first gender role attitudes scale (GRA-1) include items that tap individual choices and gender roles in the public sphere and particularly women's labor force participation, the questions in the second gender role attitudes scale (GRA-2) covers attitudes to familial roles and the private sphere. Moreover, the first gender role attitudes scale seems to reflect statements of egalitarianism directly, while the second gender role attitudes scale measures gender-egalitarianism indirectly by measuring the degree of adherence to traditional norms. 
Tab. 1: Factor loadings for gender role attitudes items in individualism and family oriented categories

\begin{tabular}{l} 
Gender role attitude 1, \\
Individualism/work orientation \\
If a woman wants to have a child as a single parent and she does not want to have \\
a stable relationship with a man, she should be able to have the child. \\
It is OK for a person to decide not to marry. \\
It is OK for a person to decide not to have children. \\
A working mother can establish just as warm and secure a relationship with her \\
children as a mother who does not work. \\
Having a job is the best way for a woman to be an independent person. \\
Both the man and the woman should contribute to the household income. \\
\hline Gender role attitude 2, \\
family orientation \\
A married couple should have at least one child. \\
A person has to have at least one child in order to be fulfilled. \\
When there are children in the family, parents should stay together even if they do \\
not get along. \\
Being a housewife is just as fulfilling as working for pay. \\
A preschool child is likely to suffer if his/her mother works. \\
A job is all right, but what most women really want is a home and children.
\end{tabular}

Cronbach's alpha

Source: author's analysis of survey data from "Fertility, Family Life and Developmental Idealism in Urban Turkey" (2014)

While the answers of these questions were categorized with a five-point Likert scale ranging from (1) "strongly agree" to (5) "strongly disagree," I recoded the variables into three answers: (1) "disagree", (2) "neither", and (3) "agree". For each of the gender role attitudes scales, the range of scores goes from a minimum of 6 (those with the most traditional gender role attitudes) to a maximum 18 (those with the most egalitarian views on gender roles). The scales in the second set were reversed so that higher scores also indicate more egalitarian attitudes. For the analysis, the gender role attitudes measure was divided into three categories: traditional, intermediate, and egalitarian using K-mean cluster analysis. For the first gender role attitude scale (GRA-1), cluster one represents "traditional" with the threshold scores being 6-11, cluster two is labelled "intermediate" with scores ranging from 12-14, and cluster three is "egalitarian" with scores from 15-18.

For the second gender role attitude scale (GRA-2), the first cluster is "traditional" from 6-9, the second cluster, "intermediate", ranging from 10-13 and the final cluster, "egalitarian", from 14-18. 
Other variables in the model include standard controls such as age, education, employment, age at first marriage, having a son, sibling size, number of children, ethnicity, and religiosity. The education variable (that of respondents and their spouses) was constructed by dividing education in to three categories based on the number of years of schooling; 0-8, 9-12, and 13 years and above. Employment status was created as a binary variable ( $0=$ does not have a job; $1=$ has a job). Age, along with age at first marriage, were included in the analyses as interval variables coded in years. The number of children is grouped into three categories: one, two, and three and more children. Religiousness was measured with a single question asking whether or not the respondents think of themselves as a religious person, with the answer categories of "no" and "yes" (coded no $=0$ and yes =1.) Two main ethnic categories were identified, Turks and non-Turks, with non-Turks representing mainly the Kurdish population which constitutes the largest ethnic minority in Turkey. In Turkey, fertility patterns vary to a great extent by ethnic identity. In eastern Turkey, where Kurdish populations predominate, the TFR is on average 3.41 births per woman (HUIPS 2014).

Also included in the model are the number of siblings and a binary variable for having a son. The number of siblings is known to correlate with fertility, as individuals' family background, i.e. coming either from a large or small family, may influence their family size preferences (Miettinen et al. 2011). The number of siblings is asked with a question on how many siblings the interviewee had in their household while growing up (including themselves; the answers are categorized as fewer than 2 siblings $=0 ; 2$ and more siblings $=1$ ). Studies show that there is a strong correlation between son preference and fertility intention and behavior. For example, parents with a son preference may want to have additional children until the desired gender composition is reached (Park/Cho 1995). This variable is included in the analyses as a binary variable coded 1 if the respondent has a son.

\section{$4 \quad$ Results and discussion}

\subsection{Descriptive statistics}

The descriptive table of the sample (Table 2), shows that close to half of the mothers and slightly more than half the fathers fit into the egalitarian category. Over onethird of mothers and one-fourth of fathers are intermediate, while over one-fifth of both female and male parents are traditional. In the second gender role attitudes scale, covering family orientation, the traditional category contains the majority of respondents. Half of the female parents and more than one-third of the male parents fit into the intermediate category and less than 10 percent are egalitarian.

With regard to the demographic variables, Table 2 shows that the mean age of female interviewees was 35.7 and that of male respondents was 37.8, most likely because women marry younger than men do. While mothers commonly have primary education, fathers have secondary and tertiary education more often than mothers do. Regarding spouses' education, a similar picture can be observed: 
Tab. 2: $\quad$ Sample characteristics (\% or mean)

\begin{tabular}{|c|c|c|}
\hline & Female parents & Male parents \\
\hline \multicolumn{3}{|l|}{ Intention to have another child } \\
\hline Yes & 30.2 & 35.6 \\
\hline No & 69.5 & 64.4 \\
\hline Missing & 0.3 & - \\
\hline \multicolumn{3}{|c|}{ GRA-1. Individualism/work orientation } \\
\hline Traditional & 20.9 & 22.5 \\
\hline Intermediate & 32.5 & 26.1 \\
\hline Egalitarian & 46.6 & 51.4 \\
\hline \multicolumn{3}{|l|}{ GRA-2. Family orientation } \\
\hline Traditional & 41.4 & 58.6 \\
\hline Intermediate & 49.6 & 35.6 \\
\hline Egalitarian & 9.0 & 5.9 \\
\hline Age (years) & 35.7 & 37.8 \\
\hline Age at first marriage (years) & 20.3 & 24.2 \\
\hline Missing \% & 0.9 & 2.9 \\
\hline \multicolumn{3}{|l|}{ Education (years) } \\
\hline $0-8$ & 66.4 & 48.0 \\
\hline $9-12$ & 25.1 & 34.0 \\
\hline $13+$ & 8.4 & 18.0 \\
\hline \multicolumn{3}{|l|}{ Spouse's education (years) } \\
\hline $0-8$ & 57.5 & 58.1 \\
\hline $9-12$ & 27.4 & 27.3 \\
\hline $13+$ & 14.5 & 14.0 \\
\hline Missing & 0.6 & 0.7 \\
\hline \multicolumn{3}{|l|}{ Has a job } \\
\hline Yes & 16.1 & 88.1 \\
\hline No & 83.9 & 11.9 \\
\hline \multicolumn{3}{|l|}{ Spouse has a job } \\
\hline Yes & 87.9 & 19.1 \\
\hline No & 12.1 & 80.9 \\
\hline \multicolumn{3}{|l|}{ Number of Children } \\
\hline 1 & 24.1 & 27.5 \\
\hline 2 & 42.3 & 41.0 \\
\hline $3+$ & 33.6 & 31.5 \\
\hline \multicolumn{3}{|l|}{ Has a son } \\
\hline Yes & 78.1 & 77.7 \\
\hline No & 21.9 & 22.3 \\
\hline
\end{tabular}

Female parents' spouses have a higher share of secondary and tertiary education, and male parents' spouses have a lower level of higher education. In sum, men on average have higher education than women, which is consistent with the general patterns in Turkey. Almost all of the fathers have a job, as opposed to only one-fifth 
Tab. 2: Continuation

\begin{tabular}{lcc}
\hline & Female parents & Male parents \\
\hline Sibling & & \\
$\quad$ Fewer than 2 & 14.9 & 10.4 \\
2 and more & 84.0 & 89.2 \\
Missing & 1.1 & 0.4 \\
Ethnicity & & \\
$\quad$ Turks & 70.3 & 73.0 \\
Kurds and others & 29.7 & 25.7 \\
Missing & - & 1.4 \\
Religiosity & & \\
Religious & 84.8 & 76.1 \\
Not religious & 14.6 & 23.6 \\
Missing & 0.6 & 0.2 \\
\hline Total N & 676 & 444 \\
\hline
\end{tabular}

Source: author's analysis of survey data from "Fertility, Family Life and Developmental Idealism in Urban Turkey" (2014)

of mothers being employed, and this gender gap in employment rates also holds true when the mothers' and their spouses are considered. While around one-fourth of parents have one child, over two-fifths have two children, and slightly over onethird have three or more children.

The childbearing patterns of the parents in the study are consistent with the country's fertility trends, where the two-child norm has prevailed for the past several decades. Around four-fifths of both men and women have at least one son. An overwhelming majority have more than two children. Almost every third parent in the sample is not Turkish, with the non-Turks being predominantly Kurdish since Kurdish people are the largest ethnic minority in Turkey, constituting 14 percent of the country's population, (Konda 2011). A vast majority of fathers describe themselves as religious and an even higher share of mothers do so.

Table 3 shows descriptive statistics for the distribution of gender role attitudes and fertility intentions. The descriptive statistics display no association between gender role attitudes and the intention to have a child. In the first gender role attitudes scale (individualism/work orientation), intermediate men seem to intend to have more children, somewhat more often than traditional and egalitarian men do. In the second gender role attitudes scale (family orientation), a slightly higher share of egalitarian men intends to have an additional child. Among female parents across both gender role attitudes scales, it is somewhat more common that intermediate mothers intend to have more children than other mothers. 
Fig. 1: Basic descriptions of relevant key variables: Intention of having one more child and gender role attitudes for female and male parents

Intention for one more child

\section{Male parents}

400

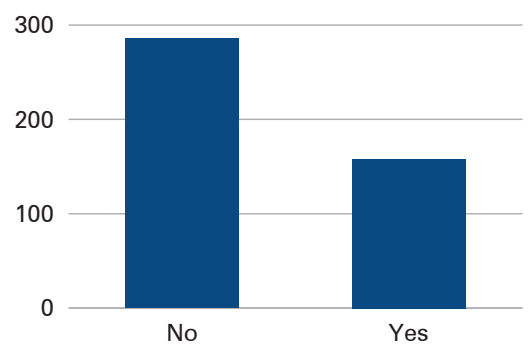

Female parents

400

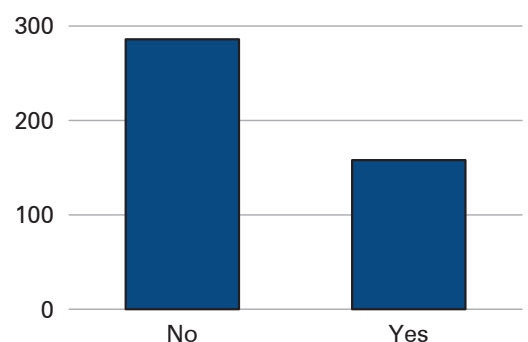

Gender role attitudes

Male parents

400

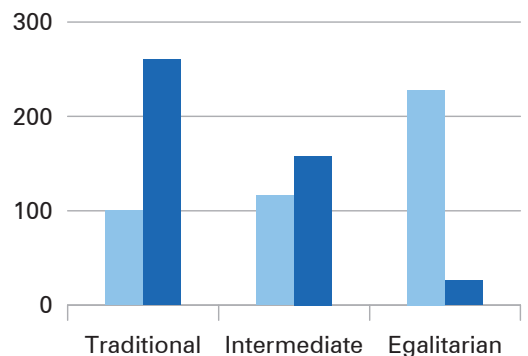

Female parents

400

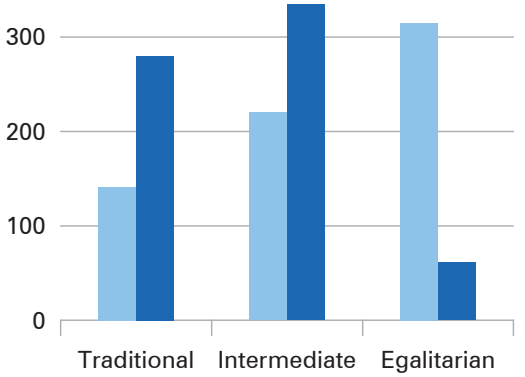

GRA-1. Individualism / work orientation

GRA-2. Family orientation

Source: author's analysis of survey data from "Fertility, Family Life and Developmental Idealism in Urban Turkey" (2014) 
Tab. 3: Descriptive statistics of effects of gender role attitudes on intensions to have more children for both male and female parents

\begin{tabular}{|c|c|c|c|c|}
\hline \multicolumn{5}{|c|}{ Intends to have a or another child } \\
\hline & \multicolumn{2}{|c|}{ Male parents } & \multicolumn{2}{|c|}{ Female parents } \\
\hline & $\mathrm{N}$ & $\%$ & $\mathrm{~N}$ & $\%$ \\
\hline \multicolumn{5}{|c|}{ GRA-1. Individualism/work orientation } \\
\hline Traditional & 100 & 34.0 & 141 & 30.5 \\
\hline Intermediate & 116 & 41.4 & 219 & 35.2 \\
\hline Egalitarian & 228 & 33.3 & 314 & 26.8 \\
\hline$x^{2}(2)$ & & 2.313 & & 4.326 \\
\hline p-value & & 0.315 & & 0.115 \\
\hline \multicolumn{5}{|c|}{ GRA-2. Family orientation } \\
\hline Traditional & 260 & 35.0 & 279 & 28.0 \\
\hline Intermediate & 158 & 36.1 & 334 & 32.3 \\
\hline Egalitarian & 26 & 38.5 & 61 & 29.5 \\
\hline$x^{2}(2)$ & & 149 & & 1.399 \\
\hline$p$-value & & 0.928 & & 0.497 \\
\hline
\end{tabular}

Source: author's analysis of survey data from "Fertility, Family Life and Developmental Idealism in Urban Turkey" (2014)

\subsection{Regression analyses}

This study draws on cross-sectional data observing individuals at a single point in time. The study sample included currently married men and women with at least one child, leading me to use a model that does not censor data. Given that the dependent variable (intention for one more child) is binary, I used binary logistic regression models to examine the association between gender role attitudes and fertility intentions separately among male and female parents. The binary logistic regression model estimates the probability that parents intend to have an additional child. The dependent variable takes a value of 1 if the respondent intends to have another child and a value of 0 if the respondent does not. Pregnant women are excluded from the sample, so the beginning of pregnancy is not considered while constructing the dependent variable. Results are expressed as Average Marginal Effects (AME); i.e. as the difference in the predicted probability of the variable of interest relative to its reference category. As a robustness check, estimations are repeated using a linear probability model (LPM), the results of which are presented in the appendix.

In line with the first research question of this study, which asks whether there is an association between parents' gender role attitudes and their fertility intentions for an additional child in Turkey, the first three models of Table 4 and Table 5 present the estimates from the logistic regression models for mothers and fathers. The first and second models are bivariate analyses with the gender role attitudes scales included in the models in a stepwise manner. The third model includes a combined 
model of the two gender role attitudes scales, which cover individualism/work and family orientations.

Examining the gender role attitudes scale on individualism/work orientation (GRA-1), the notable results for male interviewees concern the intermediate category; intermediate men tend to have a 7.2 percentage point higher likelihood of wanting more children than men with traditional values do ( $p$-value $=0.266$ ) The results do not reveal an influence of egalitarianism on fertility intention, with egalitarian men being 0.7 percentage points less likely to intend to have more children ( $p$-value $=0.906$ ), with both results statistically nonsignificant.

Examining the gender role attitudes scale on family orientation (GRA-2), the associations are positive, although they still do not reach statistical significance. Intermediate men tend to a have 1.1 percentage point higher likelihood of choosing additional childbirth than traditional men do ( $p$-value $=.823$ ), while egalitarian men are 3.4 percentage points more likely to intend to have more children ( $p$-value $=0.725$ ). Similar results were obtained when the two gender role attitudes scales were combined in a third model. Neither the separate analyses nor the combined model of gender role attitudes for fathers yield substantively and statistically significant results. However, caution is advised when interpreting the results, since the confidence intervals preclude any definitive conclusions from these estimations.

For mothers, being egalitarian seems to be negatively associated with fertility intentions in the first gender role attitudes scale in Model 1 (AME $=-.038$, $\mathrm{p}$-value $=.410$ ) and Model 3 (AME $=-.036, \mathrm{p}$-value $=.438$ ). Intermediate mothers, in all three gender role attitude scales (M1-M3), have a 4 percentage point higher likelihood of planning for more children than traditional women do. However, none of these estimates reach statistical significance. Moreover, the width of confidence intervals for these key variables is notably large and includes zero, suggesting that one should be cautious to draw a precise conclusion as to the association between gender role attitudes and fertility intentions.

Overall, the most noticeable result in these estimates is that both egalitarian men and women tend to have a lower desire for having more children than the traditional parents do. This is an expected finding, which is likely linked to the particular issues asked of respondents in each gender role attitudes question. I surmise that the items related to individualism/work orientation, including single parenting, voluntary childlessness, and women's independence through employment correspond with liberal and egalitarian values associated with a modern/western lifestyle. In the Turkish context, research shows that late and low fertility is also understood as an attribute of a modern family lifestyle considered prevalent in western countries (Kavas/Thornton 2019). So, it is likely that people holding egalitarian attitudes may not have a positive view of a large family and thus they may have a lower intention for continued childbearing. Taken together, while egalitarian parents' lower desire for more children partly supports the outlined expectations, the statistically nonsignificant results coupled with the width of confidence intervals are contrary to the study hypothesis predicting a strong association. Nevertheless, even though the data do not provide the statistical power to draw any firm conclusions, findings 


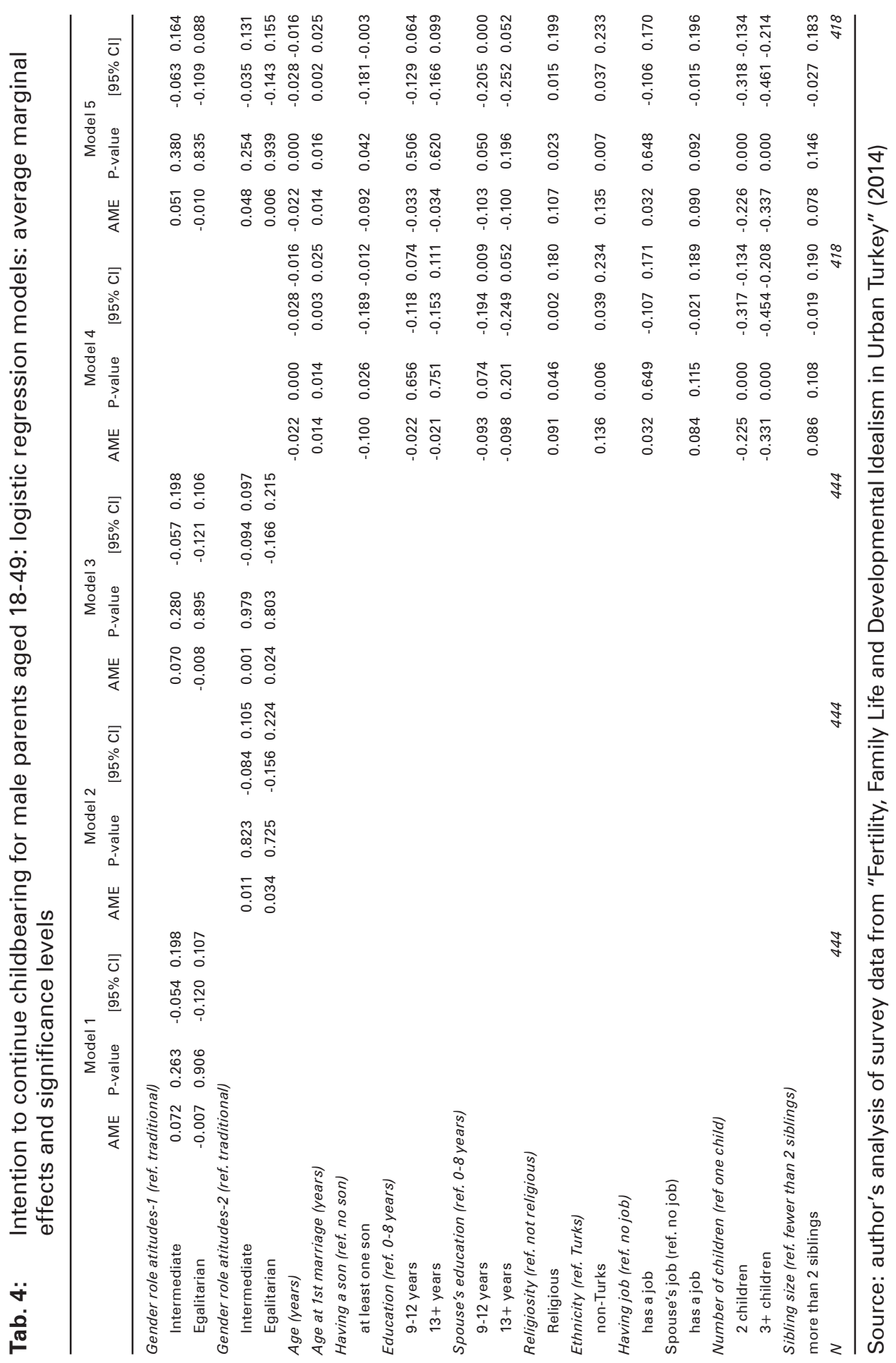




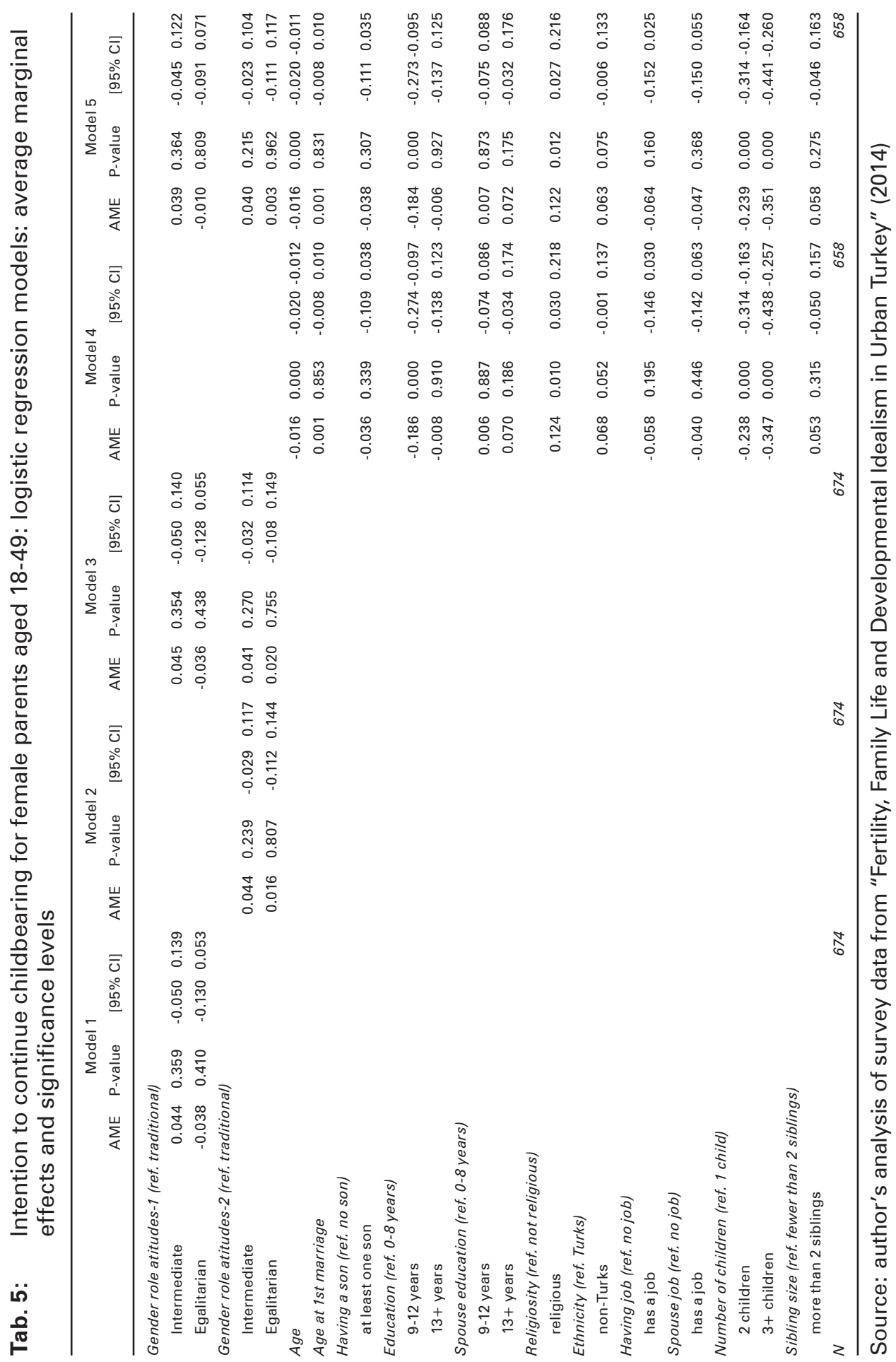


suggest slight variations between the categories of gender role attitudes and their relations to fertility intentions.

Model 5 estimates the influence of the control variables in line with the second research question which asks whether the influence of gender role attitudes on fertility persists once background factors are controlled for. For both men and women, the fully controlled model does not yield substantively or statistically significant results concerning parents' gender role attitudes and fertility intentions. However, the results highlight the importance of some of the characteristics of parents included in these full models (Table 4 and Table 5). For example, fertility intention was shown to be associated with respondents' age for both fathers and mothers, with older parents having a lower desire to have more children (men: AME $=-.022, p$-value $=0.000 ;$ women: $\mathrm{AME}=-.016, p$-value $=.000$ ). Marital timing seems to be a predictor of fertility intentions, as parents who delayed marriage seem to plan the transition to higher-order birth 1.4 percentage points more frequently than early marrying parents do ( $p$-value $=.016)$. Interestingly, this association is particularly significant for fathers, which may be because men delay marriage more often than women in Turkey (TurkStat 2020). For fathers, the sex composition of children appears to be significant; parents who have at least one son tend to lower their intention for an additional child and this association seems to be strong (AME $=.092, \mathrm{p}=.042$ ). This observed association is consistent with recent work which found that Turkish parents show a strong son preference through "son-biased fertility behavior," and are more likely to discontinue childbearing after a male birth (A/tındağ 2015). For mothers, as expected, parents with mid-level education are 18.4 percentage points less likely to intend for more children than parents with lower education $(p=.000)$; in an additional analysis that only controls for age, this negative association becomes even stronger, indicating that part of the association can be explained with the influence of age on respondents' fertility intentions. However, having a high level of education does not seem to have a similar influence on fertility (AME $=.006, \mathrm{p}$-value $=.927$ ), although this surprising finding may be due to the small sample size for the category ( $n=57$ ). Religiosity is positively associated with higher fertility for both sexes (men: AME $=107$, $\mathrm{p}$-value $=.023$; women: $\mathrm{AME}=.122, \mathrm{p}$-value $=.012$ ), which is consistent with the literature (see Adsera 2006; Philipov/Berghammer 2007 for similar findings). Islam has explicit rules related to getting married and having children, with large families and multiple children being encouraged. These discourses permeate norms and values about family and fertility. Being non-Turk (this predominantly refers to the Kurdish population) is associated with higher fertility intentions for both fathers and mothers (men: $\operatorname{Exp}(B)=.135, p$-value $=.007$; women: $\operatorname{Exp}(B)=.063$, $\mathrm{p}$-value $=.075)$, although caution is needed when interpreting these results for women, as the estimate is imprecise. The association between being non-Turk and having a large family is expected, as Kurds on average have a higher total fertility in general and the highest third birth risk (Yavuz 2006).

As expected, the number of children is significantly and negatively correlated with a plan to have more children. For both fathers and mothers, compared to one-child parents, parents with two children are 22.6 and 23.9 percentage points, 
respectively, less likely to desire more children ( $p$-value $=.000$ ) and parents with three and more children are 33.7 and 35.1 percentage points, respectively, less likely to plan to continue childbearing $(p$-value $=.000)$. This result is conceivable for Turkish parents, as having a large family with three and more children is not very common. Clearly, for Turkish parents, the first child having a sibling is a more important determinant for continued fertility than having a larger family, and this pattern seems to hold for the study sample (see Miettinen et al. 2011 for an example in Finland).

The third research question of this study is tested in a separate model (Model 4) where demographic variables are explored independently of the gender role attitudes. The results are largely similar to the fully controlled model (Model 5). The results in Model 4 further provide some indication that parents' individual and family characteristics such as age, marital timing, education, religiosity, ethnicity, number, and the sex composition of children tend to shape parents' fertility decision-making independently of their gender role attitudes.

As further robustness checks, I ran linear regression models, (i.e., a linear probability model) separately for men and women, estimating both bivariate and multivariate analyses. These estimations yield almost identical results, which suggests that the estimates from the logistic models are robust. Tables for the robustness checks are presented in the appendix.

\section{Conclusion}

In this paper, the relationship between Turkish parents' gender role attitudes and their fertility intentions for an additional child is examined. The empirical expectations were drawn from the theoretical contributions of McDonald (2000a/b, 2006), who proposed that as societies move from traditional to egalitarian, people's reproductive choices change. The timeframe in which gender equality in the institutional sphere is achieved yet societal adaptation to new changes is ongoing is of particular interest, with an expectation of fertility decline. In this study, I attempted to investigate this relationship using individual-level data and studied Turkey, where changes toward gender equality in the public sphere have not been adopted in the private sphere with persistent fertility decline accompanying these changes.

Overall, the findings of this study do not provide strong evidence that Turkish parents' gender role attitudes are associated with their fertility intentions. In particular, the results of this study neither support nor contradict the theoretical framework by McDonald (2000a/b, 2006) about the nexus between gender equity and fertility in the Turkish setting. The results of this study are consistent with a previous work by Philipov (2008) who examined gender role-fertility relationships in ten European countries and found no relationship between the various dimensions of gender roles and intentions to have or not to have a second- or higher-order child.

The lack of significant findings supporting the expected effects may be related to the small sample size used in the regression analyses, moreover, it may also be related to measurement issues, a concern which has been raised in previous 
research (e.g., Arpino et al. 2015; Brinton/Lee 2016; Knight/Brinton 2017; Miettinen et al. 2011; Mills 2010; Westoff/Higgins 2009). The questions used to measure gender role attitudes are frequently used in other surveys and have been proven to be reliable and valid (Davis/Greenstein 2009). However, it might be that these survey items measure gender role attitudes broadly, without addressing relevant aspects of gender roles in the Turkish setting. Since inequality is particularly evident within the family in Turkey, survey items that capture attitudes about gender equality in the family sphere could reveal more relevant aspects of gender roles in Turkey than those examining the public sphere. These could include questions related to the division of housework and care between mothers and fathers. Moreover, questions that tap the degree of adherence to the traditional norms about marriage timing, divorce, and beliefs regarding "honor" and virginity could unravel a more nuanced depiction of attitudes about men's and women's roles in family and social life. In this sense, using vignettes that introduce cases closely tailored to the study setting, for instance, may be a better approach for measuring gender roles and their connection to fertility decisions in Turkey.

Moreover, in line with the multidimensionality discussions in the literature (e.g. Brinton/Lee 2016; Knight/Brinton 2017; Hudde 2018), constructing a diverse range of gender ideology profiles could better measure attitudes regarding gender roles in Turkey. For example, in a recent work, Lee and Brinton identified "pro-work conservatism," which prescribes that women participate in the labor market while maintaining their primary role in the home. Even though the authors argue that pro-work conservatism is prevalent in low-fertility countries such as Japan, South Korea, and several societies in Southern and Eastern Europe, I speculate that a spectrum of more nuanced gender ideology profiles such as pro-work conservatism could reflect gender relations in Turkey more closely. Importantly, the regression analysis suggests that structural factors were more important driving forces of Turkish parents' childbearing plans than their gender role attitudes. The decision to have an additional child may not be an easy one for Turkish parents, as the cost of childbearing in Turkey is considerable. Most people are concerned about providing a decent education, clothing, and food for their children, given Turkey's economic uncertainty. Moreover, the current Turkish welfare system does not reach all strata of society and does not meet peoples' expectations (Grütjen 2008). Therefore, under these socio-economic conditions, planning for a larger family requires a very careful cost-benefit calculation. On the other hand, Turkey is a patriarchal society with a diverse ethnic population; therefore, the consistent and significant impact of ethnicity and son preference on parents' fertility decision-making is not surprising. Finally, the observed effect of religiosity on fertility intention is to be expected, since the conservative Muslim community in Turkey - especially the recent government's discourses and policy efforts to return to the traditional family - certainly influence in Turkey today (Kaya 2015; Yazıcı 2012).

This study has a number of limitations. The most relevant one is that the data come from a sample of urban residents rather than a nationally representative sample. This limits the generalizability of the study's results to the entire country. To the extent that attitudes to gender roles are different in rural and urban contexts, 
the sample results would diverge from national results. However, I argue that the rapid urbanization in recent decades and currently the substantial rural elements in urban centres may mediate these limitations to some extent.

Another limitation is that the data used for this study is restricted to currently married parents at parity 1, 2, 3 and above, aged between 18 and 49 . While this data restriction is based on the research question, a larger sample including people with different parental and marital status could yield different results.

A third limitation is that the study had to omit variables such as respondents' income and childcare arrangements. Living in a society with persistent economic insecurity and a high rate of unemployment, individuals with low income and precarious job conditions will likely prefer lower fertility than individuals without these difficulties. Also, it would have been useful to include the childcare arrangement as a predictor; it is likely that a lack of affordable and quality public childcare provision for the employed population forces parents to limit their fertility, particularly when they don't have strong support networks (such as grandparents and other relatives), as is the case with most employed parents in Turkey.

Finally, data for this study was collected from the respondents but not their spouses, which restricts the empirical analysis in two ways. First, as previous research has found, fertility decisions are usually taken at the couple level; for example, when there is no consensus regarding fertility decisions, the likelihood of having a or another child decreases (e.g. Thomson/Hoem 1998). Second, discrepant gender role attitudes between partners may influence fertility decisions (Aassve et al. 2014; Arpino et al. 2015; Hudde/Engelhart 2020). For example, similar or discordant gender role attitudes between partners may lower the risk of the transition to parenthood (Hudde/Enge/hart 2020) as well as having a second child (Aassve et al. 2014). Future research should expand on the link between gender relations and fertility intentions by considering couple-level dynamics and their gender-related attitudinal characteristics.

\section{Acknowledgements}

This study was supported by a grant from the Scientific and Technological Research Council of Turkey (TUBITAK), (SOBAG 3501, Grant \#113K073). I appreciate the staff including the interviewers and supervisors of research firm, Frekans, for their work in the collection and processing of the data. I thank Dr. Hüseyin Kavas for his input into the data analysis. Special thanks to Alice Sage and Sue Peters for their editorial help during the preparation of this article.

\section{References}

Aassve, Arnstein; Fuochi, Giulia; Mencarini, Letizia 2014: Desperate housework: relative resources, time availability, economic dependency, and gender ideology across Europe. In: Journal of Family Issues 35,8: 1000-1022. https://doi.org/10.1177/0192513X14522248 
Adsera, Alicia 2006: An economic analysis of the gap between desired and actual fertility: Case of Spain. In: Review of Economics of the Household 4,1: 75-95. http://doi.org/10.1007/s11150-005-6698-y

Akadlı-Ergöçmen, Banu 1997: An Overview of Women's Status and Fertility in Turkey. In: Cosio-Zavala, Maria Eugenia (Ed.): Women and Families: Evolution of the Status of Women as Factor and Consequence of Changes in Family Dynamics. Paris, CICRED: 79-105.

Aksoy, Ozan; Billari, Francesco 2018: Political Islam, Marriage, and Fertility: Evidence from a Natural Experiment. In: American Journal of Sociology 123,5: 1296-1340. https://doi.org/10.1086/696193

Altındağ, Onur 2015: Son Preference, Fertility Decline and Non-Missing Girls of Turkey. Paper presentation, Population Association of America. San Diego, California.

Arpino, Bruno; Esping-Andersen, Gosta; Pessin, Léa 2015: How do changes in gender role attitudes towards female employment influence fertility? In: European Sociological Review 31,3: 370-382. https://doi.org/10.1093/esr/jcv002

Assaad, Raugi; Roudi-Fahimi, Farzaneh 2007: Youth in the Middle East and North Africa: Demographic Opportunity or Challenge? Washington: Population reference bureau [https://www.prb.org/youthinmena/, 01.09.2019].

Ataca, Bilge; Sunar, Diane 1999: Continuity and change in Turkish urban family life. In: Psychology and Developing Societies 11,1: 77-90. https://doi.org/10.1177/097133369901100104

Aycan, Zeynep 2004: Key success factors for women in management in Turkey. In: Applied Psychology: An International Review 53,3: 453-477. https://doi.org/10.1111/j.1464-0597.2004.00180.x

Aycan, Zeynep; Eskin, Mehmet 2005: Relative Contributions of Childcare, Spousal Support, and Organizational Support in Reducing Work-Family Conflict for Men and Women: The Case of Turkey. In: Sex Roles 53: 453-471. https://doi.org/10.1007/s11199-005-7134-8

Becker, Gary 1985: Human capital, effort, and the sexual division of labor. In: Journal of Labor Economics 3: 33-58. https://doi.org/10.1086/298075

Berktaş, Ezgi 2016: Does Housework Rule? Fertility Intentions of Women in Turkey from a Gender Equity Perspective. European Population Conference (EPC 2016) [https:// epc2016.princeton.edu/papers/160086, 01.11.2021].

Brinton, Mary C.; Lee, Dong-Ju 2016: Gender role ideology, labor market institutions, and post-industrial fertility. In: Population and Development Review 42,3: 405-433. https://doi.org/10.1111/padr.161

Brinton, Mary C. et al. 2018: Postindustrial fertility ideals, intentions, and gender inequality: A comparative qualitative analysis. In: Population and Development Review 44,2: 281-309. https://doi.org/10.1111/padr.12128

Caldwell, John C.; Schindlmayr, Thomas 2003: Explanations of the fertility crisis in modern societies: A search for commonalities. In: Population Studies 57,3: 241-263. https://doi.org/10.1080/0032472032000137790

Cindoğlu, Dilek et al. 2008: The Family in Turkey: The Battleground of the Modern and the Traditional. In: Hennon, Charles B.; Wilson, Stephan M. (Eds.): Families in a Global Context. New York: Routledge: 235-263. https://doi.org/10.4324/9780203836941

Cooke, Lynn Prince 2009: Gender equity and fertility in Italy and Spain. In: Journal of Social Policy 38,1: 123-140. https://doi.org/10.1017/S0047279408002584 
D’Addato, Agata; Vignoli, Daniele; Yavuz, Sutay 2007: Towards Smaller Family Size in Egypt, Morocco and Turkey: Overall Change Over Time or Socio-economic Compositional Effect? MPIDR Working Paper WP-2007-012. Max Planck Institute for Demographic Research. https://doi.org/10.4054/MPIDR-WP-2007-012

Davis, Shannon N.; Greenstein, Theodore N. 2009: Gender ideology: Components, predictors, and consequences. In: Annual Review of Sociology 35: 87-105. https://doi.org/10.1146/annurev-soc-070308-115920

Erder, Nejat 2002: Türkiye'de Siyasi Partilerin Yandas/Seçmen Profili, 1994-2002. Istanbul: TUSES Publications.

Fikret-Pasa, Selda; Kabasakal, Hayat; Bodur, Muzaffer 2001: Society, organizations, and leadership in Turkey. In: Applied Psychology: An International Review 50,4: 559-589. https://doi.org/10.1111/1464-0597.00073

Freeman, Emily et al. 2018: 'I couldn't hold the whole thing': the role of gender, individualisation and risk in shaping fertility preferences in Taiwan. In: Asian Population Studies 14,1: 61-76. https://doi.org/10.1080/17441730.2017.1386408

Goldscheider, Frances; Oláh, Livia Sz; Puur, Allan 2010: Reconciling studies of men's gender attitudes and fertility: Response to Westoff and Higgins. In: Demographic Research 22: 189-198. https://doi.org/10.4054/DemRes.2010.22.8

Goldscheider, Frances; Bernhartd, Eva; Lappegård, Trude 2015: The gender revolution: a framework for understanding changing family and demographic behavior. In: Population and Development Review 41,2: 207-239. https://doi.org/10.1111/j.1728-4457.2015.00045.x

Grunow, Daniela; Begall, Katia; Buchler, Sandra 2018: Gender Ideologies in Europe: A Multidimensional Framework. In: Journal of Marriage and Family 80:,1 42-60. https://doi.org/10.1111/jomf.12453

Grütjen, Danie/ 2008: The Turkish welfare regime: an example of the Southern European model? The role of the state, market and family in welfare provision. In: Turkish Policy Quarterly 7,1: 111-129.

HUIPS (Hacettepe University Institute of Population Studies) 2014: 2013 Turkey Demographic and Health Survey. Hacettepe University Institute of Population Studies, T.R. Ministry of Development and TÜBITAK. Ankara, Turkey [http://www.hips. hacettepe.edu.tr/tr/2018_tnsa_analiz_ve_rapor-56, 10.03.2018].

Hudde, Ansgar 2018: Societal Agreement on Gender Role Attitudes and Childlessness in 38 Countries. In: European Journal of Population 34: 745-767. https://doi.org/10.1007/s10680-017-9459-8

Hudde, Ansgar; Engelhardt, Henriette 2020: Intra-Couple (Dis)Similarity in Gender Role Attitudes and the Transition to Parenthood in Germany. In: European Sociological Review 36,6: 852-867. https://doi.org/10.1093/esr/jcaa024

IIkkaracan, Pınar 2007: Reforming the Penal Code in Turkey: The Campaign for the Reform of the Turkish Penal Code from a Gender Perspective. Institute of Development Studies.

IIkkaracan, ipek 2012: Work-Family balance and public policy: A cross-country perspective. In: Development 55,3: 325-332. https://doi.org/10.1057/dev.2012.52

Kan, Man-Yee; Hertog, Ekaterina 2017: Domestic division of labor and fertility preference in China, Japan, South Korea, and Taiwan. In: Demographic Research 36: 557-588. https://doi.org/10.4054/DemRes.2017.36.18 
Kandiyoti, Deniz 1995: Patterns of Patriarchy: Notes for an Analysis of Male Dominance in Turkish Society. In: Tekeli, Şirin (Ed.): Women in Modern Turkish Society. UK: Zed Books.

Kağıtçıbaşı, Çiğdem 1982: The changing value of children in Turkey (Publ. No. 60-E). Honolulu: East-West Center.

Kağıtçıbașı, Ciğdem 1986: Status of women in Turkey. Cross-cultural perspectives. In: International Journal of Middle East Studies 18,4: 485-499. https://doi.org/10.1017/S0020743800030804

Kavas, Serap 2019: The gendered division of housework and fertility intention in Turkey. In: Genus 75,1: 1-25. https://doi.org/10.1186/s41118-019-0068-8

Kavas, Serap; Thornton, Arland 2013: Adjustment and hybridity in Turkish family change: Perspectives from developmental idealism. In: Journal of Family History 38,2: 223241. https://doi.org/10.1177/0363199013482263

Kavas, Serap; Thornton, Arland 2019: Developmental Idealism and Beliefs About Marriage and Fertility in Turkey. In: Population Research and Policy Review 39,1: 4775. https://doi.org/10.1007/s11113-019-09525-2

Kavas, Serap; De Jong, Julie 2020: Exploring the mechanisms through which social ties affect fertility decisions in Turkey. In: Journal of Marriage and Family 82,4: 1250-1269. https://doi.org/10.1111/jomf.12668

Kaya, Ayhan 2015: Islamisation of Turkey under the AKP Rule: Empowering Family, Faith and Charity. In: South European Society and Politics 20,1: 47-69. https://doi.org/10.1080/13608746.2014.979031

Knight, Carly R.; Brinton, Mary C. 2017: One egalitarianism or several? Two decades of gender-role attitude change in Europe. In: American Journal of Sociology 122,5: 14851532. https://doi.org/10.1086/689814

Koc, Ismet; Türkyılmaz, Ahmet Sinan; Adalı, Tuğba 2014: Fertility, in 2013 Turkey Demographic and Health Survey. Hacettepe University Institute of Population Studies, T.R. Ministry of Development and TÜBITAK. Ankara, Turkey: 60-72.

Kohler, Hans-Peter; Billari, Francesco; Ortega, José Antonio 2002: The emergence of lowest-low fertility in Europe during the 1990s'. In: Population and Development Review 28,4: 641-680. https://doi.org/10.1111/j.1728-4457.2002.00641.x

Konda 2011: Kürt Meselesinde Algı ve Beklentiler. Istanbul: İletişim.

McDonald, Peter 2000a: Gender equity in theories of fertility transition. In: Population and Development Review 26,3: 427-439. https://doi.org/10.1111/j.1728-4457.2000.00427.x

McDonald, Peter 2000b: Gender equity, social institutions and the future of fertility. In: Journal of Population Research 17: 1-16. https://doi.org/10.1007/BF03029445

McDonald, Peter 2006: Low fertility and the state: the efficacy of policy. In: Population and Development Review 32,3: 485-510. https://doi.org/10.1111/j.1728-4457.2006.00134.x

Miettinen, Anneli; Basten, Stuart; Rotkirch, Anna 2011: Gender equality and fertility intentions revisited: Evidence from Finland. In: Demographic Research 24: 469-496. https://doi.org/10.4054/DemRes.2011.24.20

Miller, Warren B. 2011: Differences between fertility desires and intentions: implications for theory, research and policy. In: Vienna Yearbook of Population Research 9: 75-98. https://doi.org/10.1553/populationyearbook2011s75

Mills, Melinda etal. 2008: Gender equity and fertility intentions in Italy and the Netherlands. In: Demographic Research 18,1: 1-26. https://doi.org/10.4054/DemRes.2008.18.1 
Mills, Melinda 2010: Gender roles, gender (in) equality and fertility: an empirical test of five gender equity indices. In: Canadian Studies in Population 37: 445-474. https://doi.org/10.25336/P61310

Nauck, Bernhard; Klaus, Daniela 2008: Family Change in Turkey: Peasant Society, Islam, and the Revolution from Above. In: Jayakody, Rukmalie; Thornton, Arland; Axinn, William (Eds.): International Family Change: Ideational Perspectives. NY: Lawrence Erlbaum: 282-312.

Okun, Barbara S.; Raz-Yurovich, Liat 2019: Housework, gender role attitudes, and couples' fertility intentions: Reconsidering men's roles in gender theories of family change. In: Population and Development Review 45,1: 169-196. https://doi.org/10.1111/padr.12207

Oláh, Livia Sz. 2003: Gendering fertility: Second births in Sweden and Hungary. In: Population Research and Policy Review 22,2: 171-200. https://doi.org/10.1023/A:1025089031871

Park, Chai Bin; Cho, Nam-Hoon 1995: Consequences of son preference in a low-fertility society: Imbalance of the sex ratio in Korea. In: Population and Development Review 21,1: 59-84. https://doi.org/10.2307/2137413

Philipov, Dimiter 2008: Family-related gender attitudes. The three dimensions: "Genderrole Ideology", "Consequences for the Family", and "Economic Consequences". In Höhn, Charlotte; Avramov, Dragana; Kotowska, Irena E. (Eds.): People, population change and policies. Lessons from the population policy acceptance study. Berlin: Springer: 153-174. https://doi.org/10.1007/978-1-4020-6611-5_8

Philipov, Dimiter; Berghammer, Caroline 2007: Religion and fertility ideals, intentions and behaviour: A comparative study of European countries. In: Vienna Yearbook of Population Research 5: 271-305. https://doi.org/10.1553/populationyearbook2007s271

Puur, Allan et al. 2008: Men's childbearing desires and views of the male role in Europe at the dawn of the 21st century. In: Demographic Research 19,56: 1883-1912. https://doi.org/10.4054/DemRes.2008.19.56

Rindfuss, Ronald B.; Morgan, Philip; Swicegood, Gray 1988: A Demographic Transition: First Births in America: Changes in the Timing of Parenthood. Los Angeles: University of California Press. https://doi.org/10.1126/science.242.4876.305

Sunar, Diane; Fisek, Güler Okman 2005: Contemporary Turkish families. In: Gielen, Uwe, Roopnarine, Jaipaul (Eds.): Families in Global Perspective. Allyn \& Bacon/Pearson: 169-183.

Tazi-Preve, Irene M.; Biechlbauer, Dieter; Goujon, Anne 2004: Gender trouble and its impact on fertility intentions. In: Finnish Yearbook of Population Research 40: 5-24. https://doi.org/10.23979/fypr.44996

Thomson, Elizabeth; Hoem, Jan 1998: Couple childbearing plans and births in Sweden. In: Demography 35,3: 315-322. https://doi.org/10.2307/3004039

Torr, Berna Miller; Short, Susan E. 2004: Second births and the second shift: A research note on gender equity and fertility. In: Population and Development Review 30,1: 109. 130. https://doi.org/10.1111/j.1728-4457.2004.00005.x

TurkStat (Turkish Statistical Institute) 2016: Family Structure Survey [https://data.tuik. gov.tr/Bulten/Index?p=Aile-Yapisi-Arastirmasi-2016-21869, 01.04.2021].

TurkStat (Turkish Statistical Institute) 2020: Population statistics [http://www.turkstat. gov.tr/UstMenu.do?metod=temelist, 01.04.2021]. 
United Nations 2013: World fertility report: Fertility at the extreme [https://www.un.org/ en/development/desa/population/publications/pdf/fertility/worldFertilityReport2013. pdf, 20.11.2019].

Westoff, Charles; Higgins, Jenny 2009: Relationship between men's gender attitudes and fertility: Response to Puur et al.'s Men's childbearing desires and views of the male role in Europe at the dawn of the 21st century. In: Demographic Research 21,3: 65-74. https://doi.org/10.4054/DemRes.2009.21.3

World Bank 2012: Towards gender equality in Turkey [http://documents.worldbank.org/ curated/en/377191468120289049/Towards-gender-equality-in-Turkey-a-summaryassessment, 12.05.2019].

Yang, Juhua 2017: Gendered division of domestic work and willingness to have more children in China. In: Demographic Research 37,62: 1949-1974. https://doi.org/10.4054/DemRes.2017.37.62

Yavuz, Sutay 2006: Completing the fertility transition: Third birth developments by language groups in Turkey. In: Demographic Research 15: 435-460. https://doi.org/10.4054/DemRes.2006.15.15

Yazıcı, Berna 2012: The return to the family: welfare, state, and politics of the family in Turkey. In: Anthropological Quarterly 85,1: 103-140. https://doi.org/10.1353/anq.2012.0013

Yilmaz, Zafer 2015: "Strengthening the Family" Policies in Turkey: Managing the Social Question and Armoring Conservative-Neoliberal Populism. In: Turkish Studies 16,3: 371-390. https://doi.org/10.1080/14683849.2015.1067863

Serap Kavas, PhD ( $\varangle)$. Independent Scholar. Istanbul, Turkey.

E-mail: serapkavas@gmail.com 


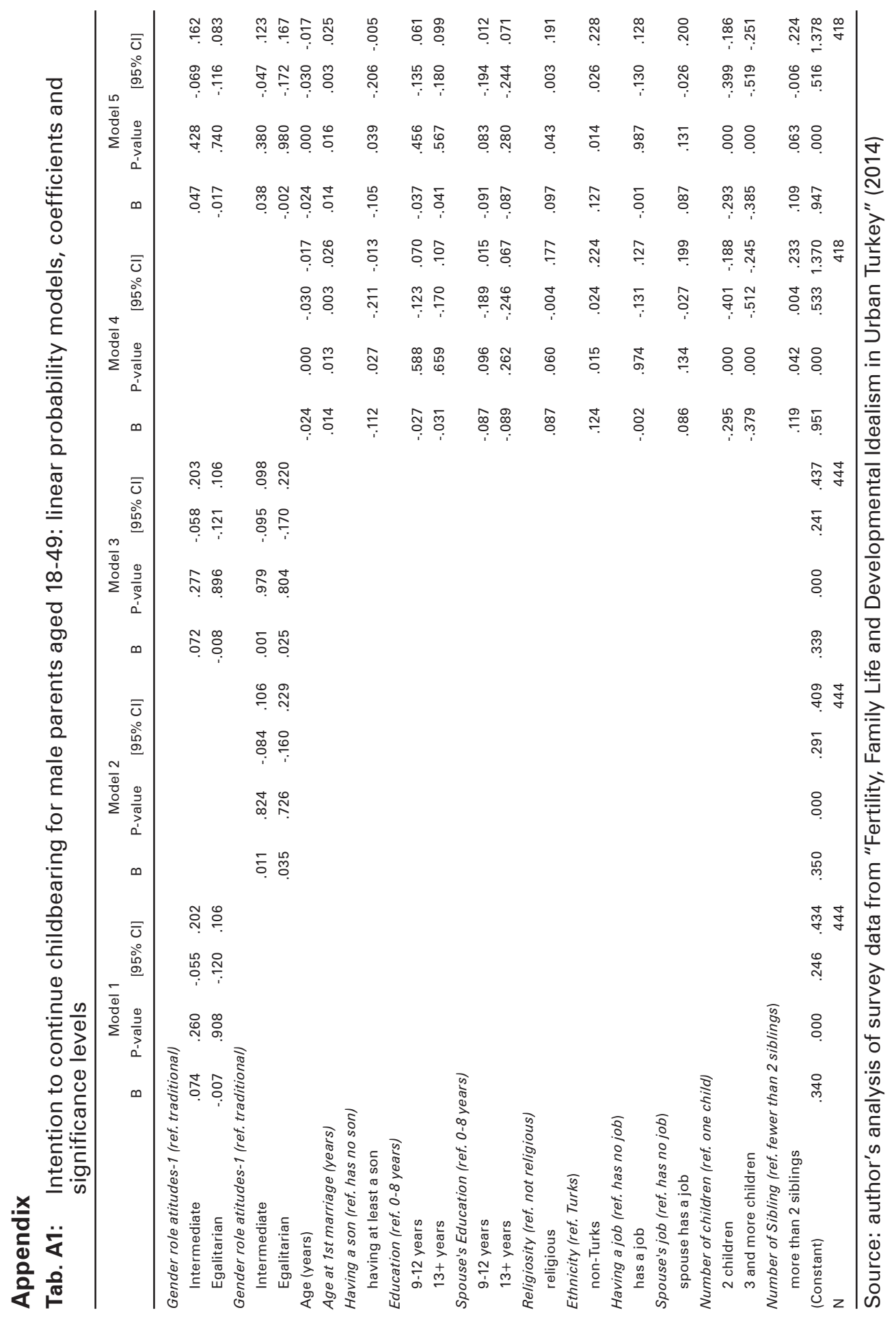




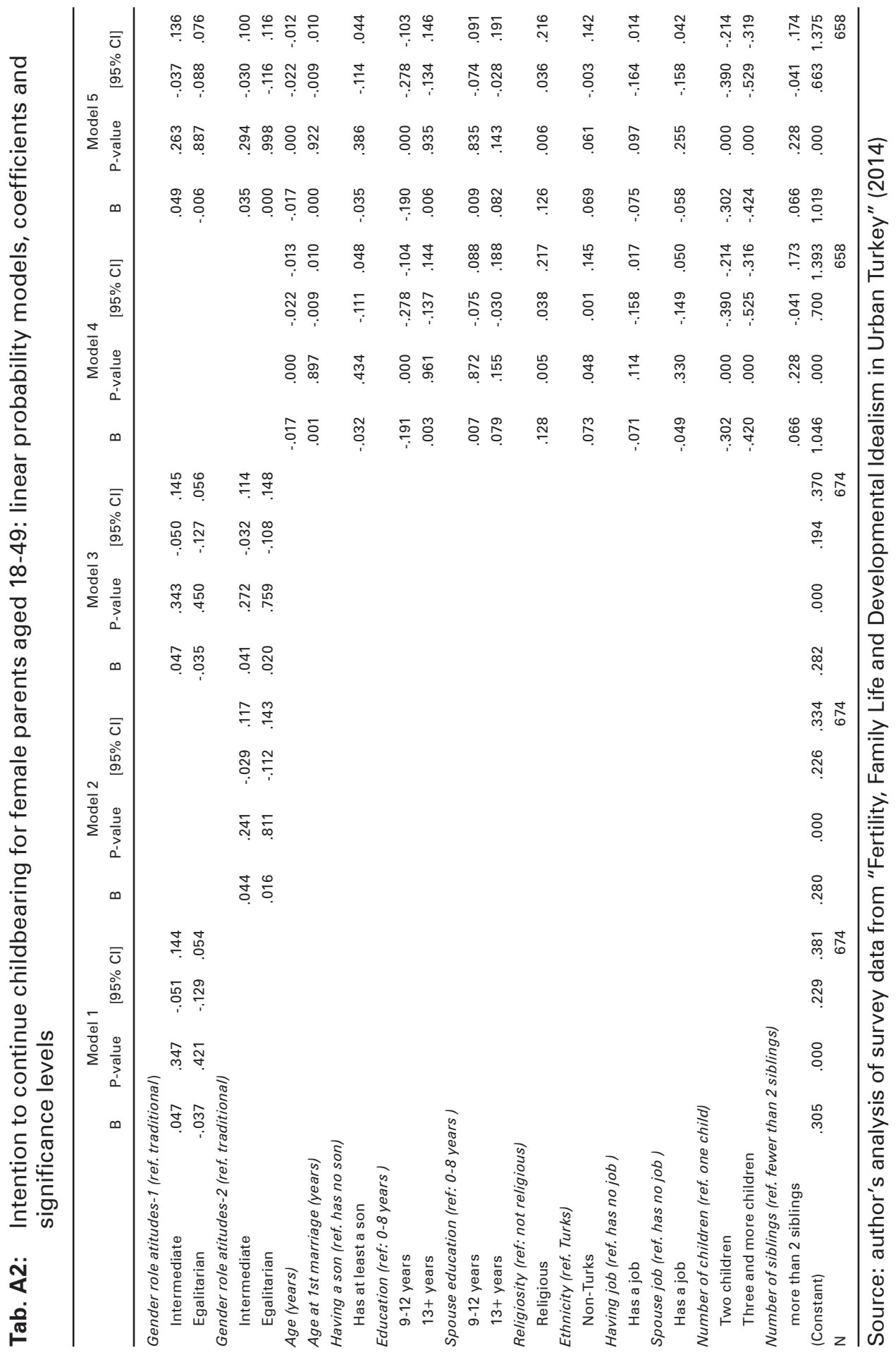




\section{Comparative Population Studies}

WWW.comparativepopulationstudies.de

ISSN: 1869-8980 (Print) - 1869-8999 (Internet)

\section{Published by}

Prof. Dr. Norbert F. Schneider

Federal Institute for Population Research D-65180 Wiesbaden / Germany

\section{(c) BY-SA}

2021

\section{Managing Editor}

Prof. Dr. Johannes Huinink

Dr. Katrin Schiefer

\section{Editorial Assistant}

Beatriz Feiler-Fuchs

Wiebke Hamann

\section{Layout}

Beatriz Feiler-Fuchs

E-mail:cpos@bib.bund.de

\section{Scientific Advisory Board}

Karsten Hank (Cologne)

Michaela Kreyenfeld (Berlin)

Marc Luy (Vienna)

Natalie Nitsche (Rostock)

Zsolt Spéder (Budapest)

Rainer Wehrhahn (Kiel)

\section{Board of Reviewers}

Bruno Arpino (Barcelona)

Kieron Barclay (Rostock)

Laura Bernardi (Lausanne)

Gabriele Doblhammer (Rostock)

Anette Eva Fasang (Berlin)

Michael Feldhaus (Oldenburg)

Tomas Frejka (Sanibel)

Alexia Fürnkranz-Prskawetz (Vienna)

Birgit Glorius (Chemnitz)

Fanny Janssen (Groningen)

Frank Kalter (Mannheim)

Stefanie Kley (Hamburg)

Bernhard Köppen (Koblenz)

Anne-Kristin Kuhnt (Duisburg)

Hill Kulu (St Andrews)

Nadja Milewski (Wiesbaden)

Roland Rau (Rostock)

Thorsten Schneider (Leipzig)

Tomas Sobotka (Vienna)

Jeroen J. A. Spijker (Barcelona)

Heike Trappe (Rostock)

Helga de Valk (The Hague)

Sergi Vidal (Barcelona)

Michael Wagner (Cologne) 